\title{
INHIBITION OF PATHOGENS BY SPOROGENIC BACTERIA ISOLATED FROM HONEY OF Melipona sp. (APIDAE: APINAE: MELIPONINI) ${ }^{1}$
}

\author{
KELY DAMIANA NOVAES DA SILVA ${ }^{2}$, RENAN DO NASCIMENTO BARBOSA ${ }^{3}$, PEDRO DE ASSIS DE \\ OLIVEIRA $^{2}$, MARCELO CASIMIRO CAVALCANTE ${ }^{2}$, HÉLIO FERNANDES DE MELO ${ }^{2 *}$
}

\begin{abstract}
The aim of this study was to isolate sporogenic bacteria from the honey of stingless bees Melipona sp., in dry forest, and to evaluate their antagonistic potential for medicinal employment purposes and animal production. The honey samples were collected in Serra Talhada-PE, where honey was taken from four different hives (in triplicate), totaling 12 samples. The samples were diluted and subjected to $80{ }^{\circ} \mathrm{C}$ for 20 minutes to eliminate vegetative cells. The dilutions were plated onto nutrient agar and incubated at $30{ }^{\circ} \mathrm{C}$ for 72 hours. Then the colony forming units (CFU) were quantified. The samples were also plated onto malt agar and Sabouraud agar, and incubated at $30{ }^{\circ} \mathrm{C}$ for 14 days for the growth of yeast and molds. Total and fecal coliforms were quantified by the most probable number method (MPN). Seven isolates (I) of sporogenic bacteria (Bacillus) were obtained, however only four showed probiotic potential. Isolate I-5 showed the greatest probiotic potential and inhibited the growth of Escherichia coli, Klebsiella sp., Pseudomonas aeruginosa, Salmonella sp., and Staphylococcus aureus. The growth of the Sarcina sp. was not inhibited by any isolate. No yeast, molds or coliforms were found. The Melipona sp. honey is a source of spore-forming bacteria and is antagonistic to microorganisms that contaminate honey. It has good microbiological quality.
\end{abstract}

Keywords: Stingless bee. Bacillus. Caatinga.

\section{INIBIÇÃO DE PATÓGENOS POR BACTEIAS ESPORULANTES ISOLADAS DE MEL DE Melipona sp. (APIDAE: APINAE: MELIPONINI)}

\begin{abstract}
RESUMO - Este trabalho teve como objetivo isolar bactérias esporulantes a partir do mel de Melipona sp. em ambiente de caatinga e avaliar o seu potencial antagonista com vistas à aplicação na medicina e produção animal. As amostras de méis foram coletadas no município de Serra Talhada-PE, onde o mel foi retirado de quatro colméias diferentes (em triplicata), totalizando 12 amostras que amostras foram diluídas $\left(10^{-1}\right.$ a $\left.10^{-5}\right) \mathrm{e}$ submetidas a $80{ }^{\circ} \mathrm{C}$ por 20 minutos e resfriadas a $5{ }^{\circ} \mathrm{C}$ para indução de esporos e eliminação de células vegetativas. Em seguida, as diluições foram semeadas em Agar Nutriente e incubadas a $30^{\circ}$ por 72 horas para contagem das unidades formadoras de colônias (UFC). Antes do tratamento térmico foram realizados testes para verificar a presença de fungos filamentosos, leveduras e coliformes totais e termotolerantes. As diluições foram semeadas em Agar Malte e Agar Sabouraud e incubadas a $30{ }^{\circ} \mathrm{C}$ por 14 dias. Coliformes totais e termotolerantes foram quantificados pelo método do número mais provável (NMP). Foram obtidos sete isolados (I) de bactérias esporulantes (Bacillus), porém apenas quatro mostraram algum potencial antagonista. O isolado I-5 apresentou o maior potencial antagonista, inibindo o crescimento de Escherichia coli, Klebsiella sp., Pseudomonas aeruginosa, Salmonella sp. e Staphylococcus aureus. Apenas Sarcina sp. não foi inibida. Não foram encontrados fungos filamentosos, leveduras ou coliformes nas amostras. O mel de Melipona sp. é uma fonte de bactérias esporulantes resistentes a elevadas temperaturas e com potencial antagonista a micro-organismos contaminantes e apresenta boa qualidade microbiológica.
\end{abstract}

Palavras-chave: Abelhas sem ferrão. Bacillus. Caatinga.

\footnotetext{
*Corresponding author

${ }^{1}$ Received for publication in $11 / 13 / 2014$; accepted in $05 / 30 / 2016$.

Paper extracted from graduation monograph of the first author.

${ }^{2}$ Academic Unit of Serra Talhada, Universidade Federal Rural de Pernambuco, Serra Talhada, PE, Brazil; kely.novaes23@gmail.com, pedromanari@hotmail.com, marcelufc@yahoo.com.br, heliofm43@yahoo.com.br.

${ }^{3}$ Department of Mycology, Universidade Federal de Pernambuco, Recife, PE, Brazil; renan.rnb@gmail.com.
} 


\section{INTRODUCTION}

In Brazil, honey from native bees has commonly been used to heal many bacterial and fungal diseases, as well as being a scar promoter and antioxidant (GONÇALVES et al., 2005). In vitro assays showed that honey from Nannotrigona testaceicornis and Tetragonisca angustula bees inhibited the development of Bacillus sp., Escherichia coli, Proteus spp., Pseudomonas aeruginosa, Streptococcus pyogenes, coagulasepositive Staphylococcus spp. and yeasts (GONÇALVES; ALVES FILHO; MENEZES, 2005; BOBANY et al., 2010).

On the other hand, several microorganism species can be found in the nests of stingless bees, especially bacteria, such as Bacillus, and filamentous fungi and yeast, which might contaminate not only honey, but also pollen, larvae food, and the intestines of the worker bees. In pollen and larvae food, several microorganism species provide digestive enzymes, which participate in the pre-digestion of food stores, and also organic acids and antibiotics, which inhibit the development of competitor microorganisms (GILLIAM; ROUBIK; LORENZ, 1990).

The bee intestine can carry many microorganism species, of which $1 \%$ are yeast, $27 \%$ are Gram-positive bacteria, including Bacillus, Bacteridium, Streptococcus, and Clostridium, and $70 \%$ are Gram-negative bacteria, including Escherichia, Pseudomonas, Citrobacter, Enterobacter, Erwinia, Klebsiella, Flavobacterium, and Proteus (OLAITAN; ADELEKE; OLA, 2007).

Some bacteria and fungi species secrete substances that are antagonistic to other microorganisms and that have been used as probiotics against enteric diseases of man and animals (MELLO, 2012). The discovery of new natural sources of antibiotics is important, thus a great diversity of microorganisms living in many environments, especially those environments understudied, have been explored (GUIMARÃES; MOMESSO; PUPO, 2010). Due to the large number of bacteria that are resistant to commonly used antibiotics, particularly those responsible for hospital infections, many researchers are seeking new natural biologically active substances that play roles in the control of infectious diseases (GUIMARÃES; MOMESSO; PUPO, 2010).

The bacteria that are currently used as probiotic producers are Bacillus. Despite not being considered indigenous to the intestine, spore-producing bacilli are capable of growing and surviving in the environment and in the animal's intestine. The sporulation ability confers on them a greater resistance to digestive enzymes during intestinal transit (MELLO, 2012). Rocha et al. (2010) used B. subtilis and a commercial mixture of Lactobacillus plantarum, L. bulgaricus, $L$. acidophilus, L. rhamnosus, Bifidobacterium bifidum,
Streptococcus thermophilus, and Enterococcus faecium as probiotics in broiler feed, and concluded that the birds showed better breast growth than those fed with additive-free feed.

Many organic acids produced by microorganisms, such as acetic (REZENDE et al, 2008), fumaric, and propionic (ROCHA et al., 2010) have been used as antibiotic substitutes in the feed of broilers and laying hens. Bassan et al (2008) controlled Salmonella enteritidis infection in broilers by adding formic and propionic acids, and a mannan oligosaccharide, to the feed of infected chicks.

The aim of the present study was to isolate sporogenic bacteria from Melipona sp. of the Caatinga (Brazilian dry forest) and to evaluate their antagonistic potential against other pathogenic bacteria, as well as their use in human health and animal production. The microbiological quality of honey was tested by determining the presence of filamentous fungi, yeast, and total and thermotolerant coliforms, to check whether it reached the safety requirements to be used as food for humans.

\section{MATERIAL AND METHODS}

Honey samples were collected from four Melipona sp. beehives in a natural environment of a Caatinga area, near to the PE 390 roadway in the Serra Talhada municipality $\left(08^{\circ} 06.067\right.$ to $08^{\circ} 05.756$ $\mathrm{S}$ and $\left.30^{\circ} 20,844 \mathrm{~W}\right)$. Beehives were housed in trunks of "catingueira" (Caesalpinia pyramidalis) trees taken from the natural environment for the construction of the Pajeú pipeline. Beehives were sheltered in beekeeping boxes and transferred to the apiary of the Universidade Federal Rural de Pernambuco/Academic Unit of Serra Talhada. Three pots of honey were collected from each beehive, making a total of 12 samples.

Initially, the pots were washed with $70 \%$ sodium hypochlorite and then with sterile distilled water. Then the contents of the pots were aseptically removed using disposable syringes, and then subjected to decimal serial dilutions in saline solution $(0,85 \%)$. The presence of fecal and thermotolerant coliforms was determined by the most probable number (MPN) method at $95 \%$ of confidence (SILVA; JUNQUEIRA; SILVEIRA, 2001). The dilutions were seeded onto Sabouraud agar $\left(\right.$ Himedia $\left.^{\circledR}\right)$ and malt agar $\left(\right.$ Himedia $\left.^{\circledR}\right)$, and incubated at $30{ }^{\circ} \mathrm{C}$ for 14 days to evaluate growth and to count the colony forming units (CFU) of filamentous fungi and yeast. The dilutions were subjected to hyperthermia $\left(80{ }^{\circ} \mathrm{C}\right)$ for 20 minutes followed by water cooling at $5{ }^{\circ} \mathrm{C}$ to activate spores and eliminate vegetative cells, adapting the methods described by Vittori et al. (2008). Aliquots were then seeded in $9 \mathrm{~cm}$ Petri plates, with nutrient agar $\left(\right.$ Himedia $\left.^{\circledR}\right)$, and incubated at $30{ }^{\circ} \mathrm{C}$ for up to 72 
hours for the CFU counting.

The CFU were morphologically characterized according to color, texture, the elevation and edges of colonies, and also the shape, arrangement, and size of the cells. The isolates (I) were grown on Nutrient Broth (Himedia ${ }^{\circledR}$ ) and incubated at $30{ }^{\circ} \mathrm{C}$ for up to 72 hours to verify the ring or sediment formation. Gram and spore staining procedures were performed, and the ability of the isolates to ferment glucose via the butylene glycol pathway, and to produce acetylmethylcarbinol, were assessed. Starch hydrolase and Voges-Proskauer biochemical assays were tested (GARRITY et al, 2004). The catalase assay was performed to evaluate the capability of the isolates to hydrolyze hydrogen peroxide. The ability to use citrate as sole carbon source and ferment glucose were tested using phenol red and methyl red, respectively, as $\mathrm{pH}$ reduction indicators. The reduction of nitrate to nitrite, the ability to grow in nutrient broth containing $6.5 \% \mathrm{NaCl}$, and the ability to ferment arabinose, were also assessed.

Each isolate was subjected to the agar block antagonism assay, as previously described by Stern et al. (2006) and Bonfim (2010), using de Man-Rogosa-Sharpe (MRS) agar $\left(\right.$ Himedia $\left.^{\circledR}\right)$. First, isolates were diluted in $0.85 \%$ saline solution to a final concentration of $1 \times 10^{8}$ cells $/ \mathrm{mL}$, and then seeded in triplicate onto dishes containing MRS agar. Dishes were incubated at $37{ }^{\circ} \mathrm{C}$ for 24 to 36 hours until a layer of cells formed. After the cells had grown, $6 \mathrm{~mm}$ disks of MRS agar were cut out. Escherichia coli, Klebsiella sp., Sarcina sp., Pseudomonas aeruginosa, Salmonella sp., and Staphylococcus aureus test microorganisms were diluted in $0.85 \%$ saline solution to a final concentration of $1 \times 10^{8}$ cells $/ \mathrm{mL}$, and then seeded in triplicate onto Mueller-Hilton (MH) agar $\left(\right.$ Himedia $\left.^{\circledR}\right)$. The isolate culture agar disks were inverted onto the $\mathrm{MH}$ agar surface, previously seeded with the test microorganisms. MRS agar disks without cultures were used as controls. Dishes containing disks and the test microorganism cultures were incubated at $37{ }^{\circ} \mathrm{C}$ for 24 to 36 hours. After that, the dishes were examined for inhibition ring formation, whose diameters were measured and classified according to Matsuura (2004): low (7-10 $\mathrm{mm}$ ), moderate (11-14 $\mathrm{mm}$ ), and high (above 14 $\mathrm{mm}$ ) inhibition capability.

\section{RESULTS AND DISCUSSION}

The density of sporogenic bacteria varied from 200 to $260 \mathrm{CFU} / \mathrm{g}$ of honey. Seven isolates (I1-I7) were obtained, all aerobic, mesophilic, Gram -positive, resistance spore producers, and belonging to the Bacillus genus. Isolates were present in nine of the 12 pots, representing $69 \%$ of total (Table 1 ).

Table 1. Distribution of isolates from honey pot samples (1 to 12) from four beehives (A, B, C, and D) of Melipona sp. in a Caatinga area in the Serra Talhada - PE municipality.

\begin{tabular}{ccc}
\hline BEEHIVE & HONEY POT & ISOLATE \\
\hline A & 1 & None \\
A & 2 & None \\
A & 3 & None \\
B & 4 & I-1 \\
B & 5 & I-2 \\
B & 6 & I-3 \\
C & 7 & I-4 \\
C & 8 & I-5 \\
C & 9 & I-4 \\
D & 10 & $\mathrm{I}-5$ \\
D & 11 & I-6 \\
D & 12 & I-7 \\
\hline Total & 12 & 7 \\
\hline
\end{tabular}

$\mathrm{I}=$ Isolate

Bacillus bacteria are allochthones to the honey of indigenous stingless bees; their presence in honey is due to the feeding habit of the bees and the collection of material such as clay and animal excreta for the maintenance of the nest structure, as there are no scientific reports of a co-evolutionary association between Melipona sp. bees and bacteria. The absence of sporogenic bacteria in the honey of colony A might be related to the type of food source that workers had been visiting at the time of the sample collection. Besides, colony A had a large number of subjects in a well-structured nest, where no clay or excreta had recently been collected.
Biochemical assays are essential for phenotypic characterization and are also important tools for species identification. Isolate I-5 produced organic acid from arabinose fermentation, a usual characteristic of $B$. alcalophilus and B. circulans, however none of the isolates performed acid production by glucose fermentation (Table 2), excluding the possibility of I-3, I-4, and I-6, which did not produce tumid spores, being classified as $B$. insolitus. This microorganism also does not produce tumid spores, but is able to ferment glucose and produce acid, which is an important characteristic that differentiates it from $B$. marinus. 
Table 2. Biochemical characterization assays of Bacillus sp. isolated from Melipona sp. honey from a Caatinga in the Serra Talhada - PE municipality.

\begin{tabular}{|c|c|c|c|c|c|c|c|}
\hline \multirow{2}{*}{ Assay } & \multicolumn{7}{|c|}{ Isolate } \\
\hline & $\mathrm{I}-1$ & $\mathrm{I}-2$ & $\mathrm{I}-3$ & $\mathrm{I}-4$ & I-5 & I-6 & I-7 \\
\hline Starch hydrolysis & + & - & - & - & + & - & + \\
\hline Voges Proskaeur & - & - & - & - & - & - & - \\
\hline Catalase & + & + & + & + & + & + & - \\
\hline Citrate & - & - & - & - & - & - & - \\
\hline $\begin{array}{l}\text { Glucose fermentation } \\
\text { with acid production }\end{array}$ & - & - & - & - & - & - & - \\
\hline $\begin{array}{l}\text { Glucose fermentation } \\
\text { with gas production }\end{array}$ & - & - & - & - & - & - & - \\
\hline Nitrite reduction & - & - & - & - & - & - & - \\
\hline $6.5 \% \mathrm{NaCl}$ growth & + & - & - & - & + & - & - \\
\hline Arabinose fermentation & - & - & - & - & + & - & - \\
\hline Methyl red & - & - & - & - & - & - & - \\
\hline Tumid spores & + & + & - & - & + & - & + \\
\hline Probable species & B. brevis & B. sphaericus & B. insolitus & B. badius & B. circulans & B. marinus & B. pantothenicus \\
\hline
\end{tabular}

Positive (+), Negative (-).

Organic acids decrease the $\mathrm{pH}$ of the medium, inhibiting the growth of contaminant microorganisms (REZENDE et al., 2008; ROCHA et al., 2010). The absence of glucose fermentation by the isolates indicates that bacteria do not consume the glucose present in honey, because honey is stored in the beehive in pots sealed with wax at the operculum. This sealing promotes an oxygen-free environment which leaves anaerobic metabolism as the only energy source for growth. Glucose fermentation with organic acid production is an important characteristic for the animal industry, since many of these acids have been tested as antibiotic substitutes added to the feed of broiler and laying hens (BASSAN et al., 2008; REZENDE et al., 2008; ROCHA et al., 2010).
Isolates I-1, I-5, and I-7 were able to hydrolyze starch, resulting in the production of amylase. Catalase, an important enzyme that plays a role in the oxidative stress response, was produced by $85.7 \%$ of the isolates. Only $28.6 \%$ of the isolates were able to grow in the presence of $6.5 \% \mathrm{NaCl}$, which indicates that bacteria in these isolates have a response system against osmotic stress (Table 2).

Isolate I-5 inhibited the growth of all tested bacteria except Sarcina sp., displaying good antagonistic potential. On the other hand, I-1 and I-2 inhibited E. coli, and I-3 inhibited Pseudomonas aeruginosa (Table 3).

Table 3. Test of inhibition of growth of bacterial species by Bacillus sp. isolated from Melipona sp. honey samples from a Caatinga area in the Serra Talhada - PE municipality.

\begin{tabular}{cl}
\hline Isolate & \\
\hline I-1 & E. coli \\
I-2 & E. coli \\
I-3 & P. aeroginosa \\
I-4 & None \\
I-5 & E. coli, P. aeruginosae, Salmonella sp., S. aureus, Klebisiella sp. \\
I-6 & None \\
I-7 & None \\
\hline
\end{tabular}

E. coli growth was inhibited by three isolates (I-1, I-2, and I-5; 42.86\%), while $P$. aeruginosa growth was inhibited by two isolates (I-2 and I-5, $28.57 \%$ ). On the other hand, Salmonella sp., Klebsiella sp., and $S$. aureus were inhibited only by I -5 , and Sarcina sp. was not inhibited by any isolate. The antagonistic reaction to $E$. coli might produce false negative results in the estimation of fecal contamination of the honey, since this bacterium has largely been referenced as the main indicator of food and water contamination by fecal material (SILVA;
JUNQUIERA; SILVEIRA, 2001). The presence of I-1 and I-2 can mask the presence of $S$. aureus, $P$. aeroginosa, Salmonella sp., Klebsiella sp., and Sarcina sp. in the honey of native stingless bees, because the isolates inhibited growth of the main contaminant but did not show antagonism to the tested pathogens.

The antagonistic potential of the isolates was determined by measuring the inhibition rings diameters, according to Matsuura (2004) (Table 4). 
K. D. N. SILVA et al.

Table 4. Antagonistic potential of isolates, determined by measurement of the inhibition zone (in mm) against the indicators and pathogens tested by the agar block technique.

\begin{tabular}{|c|c|c|c|c|c|c|}
\hline \multirow[t]{2}{*}{ ISOLATE } & \multicolumn{6}{|c|}{$\begin{array}{c}\text { INDICATORS OR PATHOGENS } \\
\text { (inhibition zone in } \mathrm{mm} \text { ) } \\
\end{array}$} \\
\hline & E. coli & Klebsiella sp. & Sarcina $\mathrm{sp}$. & P. aeruginosa & Salmonella sp. & S. aureus \\
\hline I-1 & 11.2 & 0.0 & 0.0 & 0.0 & 0.0 & 0.0 \\
\hline I-2 & 10.3 & 0.0 & 0.0 & 0.0 & 0.0 & 0.0 \\
\hline $\mathrm{I}-3$ & 0.0 & 0.0 & 0.0 & 20.3 & 0.0 & 0.0 \\
\hline $\mathrm{I}-4$ & 0.0 & 0.0 & 0.0 & 0.0 & 0.0 & 0.0 \\
\hline $\mathrm{I}-5$ & 24.0 & 14.5 & 0.0 & 10.6 & 14.2 & 14.9 \\
\hline $\mathrm{I}-6$ & 0.0 & 0.0 & 0.0 & 0.0 & 0.0 & 0.0 \\
\hline $\mathrm{I}-7$ & 0.0 & 0.0 & 0.0 & 0.0 & 0.0 & 0.0 \\
\hline
\end{tabular}

Results represent the averages of triplicates.

Isolate I-5 showed strong antagonism to most of the tested pathogens, making inhibition rings larger than $14 \mathrm{~mm}$ (high inhibition), except to $P$. aeruginosa, where the ring was $10.6 \mathrm{~mm}$ (moderate inhibition). The I-3 only inhibited $P$. aeruginosa, however it was the only isolate to strongly inhibit this microorganism. Results showed that isolates had genetic variability related to production of substances antagonistic to the competitor microorganisms. Isolates I-4, I-6, and I-7 did not produce any antagonistic substance that was able to diffuse through the culture medium and inhibit the growth of the tested pathogens.

In vitro assays demonstrated that the Nannotrigona testaceicornis honey inhibited the growth of Escherichia coli, Proteus spp., Pseudomonas aeruginosa, Streptococcus pyogenes, and Coagulase-positive Staphylococcus spp. (GONÇALVES; ALVES FILHO; MENEZES, 2005). Bobany et al. (2010) demonstrated that honey from Tetratrigona angustula bees presented inhibitory activity against Staphylococcus sp., Bacillus sp., and yeast. In the present study, honey from Melipona sp. can house microorganisms with antagonistic potential to certain pathogens that cause disease in humans and other warm blood animals.

Studies of symbiosis between bacteria and insects have provided new insights into chemically diverse and biologically active compounds, such as bacitracin and amicoumacin obtained from bacteria associated with Ceratophyllus sp. and Coenagrion sp., respectively (GUIMARÃES; MOMESSO; PUPO, 2010). Although symbiosis between microorganisms and bees has not yet been proved, the honey, pollen, and larval food of the stingless bees could be a source of microorganisms that produce chemically diverse and biologically active compounds that might be used in the control of infectious diseases of humans and animals.

In a pioneering study, Gilliam, Roubik e Lorenz (1990) verified the presence of $B$. circulans, $B$. alvei, and B. megaterium, which produce digestive enzymes such as proteases, galactosidases, and antimicrobial substances, in the pollen, larval food, and honey of Melipona fasciata from a rain forest in Panama. This might indicate a co-evolutionary association between bees and bacteria, as also observed between Apterostigma dentigerum ants and Pseudonocardia and Streptomyces bacteria, which secrete antimicrobial substances and control food contamination by Escovopsis sp. (CONTI; GUIMARÃES; PUPO et al., 2012). However, there is no strong evidence to support the co-evolutionary association between bees and antimicrobial substance-producing bacteria. The I-5 isolate presented similar morphological and biochemical characteristics to $B$. circulans, a species also found in the honey of $M$. fasciata in a rain forest (GILLIAM; ROUBIK; LORENZ, 1990).

In all of the evaluated samples, the concentrations of total or thermotolerant coliforms were less than $0.3 \mathrm{MPN} / \mathrm{g}$. This result agrees with those presented by Souza et al. (2009), who did not find total or thermotolerant coliforms in 14 samples of Trigonini honey produced in Bahia state, Brazil. The microbiological analysis of $M$. compressipes, M. subnitida, and M. scutellaris in Piauí state revealed that samples were free from coliforms (MONTE et al., 2013). Souza (2008) analyzed the microbiological quality of 47 samples of honey from many stingless bee species in Bahia and verified that only one was infected by coliforms. However, these authors did not suggest why samples were free from thermotolerant coliforms, and did not speculate on any relationship between the absence of these microorganisms and the presence of antimicrobial substances or antagonistic microorganisms in honey.

In contrast, Matos et al. (2011) found total and thermotolerant coliforms in 5 out of a total of 15 evaluated samples of honey from Melipona sp., with concentrations ranging from 23 to $1,100 \mathrm{MPN} / \mathrm{mL}$. Microbiological analysis of Melipona sp. honey from the Parintis municipality in Amapá revealed the presence of filamentous fungi in $80 \%$ of the samples, and thermotolerant coliforms in $33 \%$, while yeast was found in all of the samples (MATOS et al., 2011). The microbiological quality of meliponine honey depends on the climate characteristics of the region where the nests are housed. Coliform bacteria, filamentous fungi, and yeast depend on substrates with high water content in order to develop. Very dry environments may be unfavorable to the development of these microorganisms. Thus, it is 
natural that semiarid environments would be less favorable to contamination of honey by allochthone microorganisms.

It is possible that native bees possess mechanisms to avoid the contamination of stored food by bacteria harmful to the colony, but fungi have usually been found in honey (MATOS et al., 2011; MONTE et al., 2013; SOUZA, 2008). Phenolic compounds and flavonoids from plants were found in the honey of many stingless bee species, which could be responsible for the antimicrobial activity (BAZONI, 2012), however, no correlation has been found between the concentration of such compounds and the minimum inhibitory concentration of the honey against $E$. coli and $S$. aureus. Inhibition of bacteria is due to $\mathrm{pH}$ and acidity of honey (PERALTA, 2010).

It is important to consider the role of organic acid-producing bacteria, which can contribute to the acidity of the honey and, consequently, to its antimicrobial properties. Although none of the isolates produced organic acid from the fermentation of glucose, which is normally present in high quantities in honey, some were able to inhibit the growth of pathogenic bacteria, which means that these isolates must secrete antimicrobial substances of a different chemical nature. Filamentous fungi and yeast were not found in the honey samples evaluated in this work possibly due to the fact that samples had been collected during a drought, when there are not many places with humidity high enough to support their development.

\section{CONCLUSION}

In brazilian dry forest (Caatinga), in Brazil, the honey of Melipona sp. showed good microbiological quality, and is suitable for use as food for humans. Moreover, it is a good source of sporogenic bacteria resistant to high temperatures, producers of antimicrobial substances, and with good antagonistic potential inhibiting the growth of contaminant microorganisms and contributing to the microbiological quality of the stored food in the bee hive. The demonstrated antagonistic feature is not related to the production of organic acids from glucose present at high concentrations in honey.

\section{REFERENCES}

BASSAN, J. D. L. et al. Controle da infecção por Salmonella enteritidis em frangos de corte com ácidos orgânicos e mananoligossacarídeo. Ciência Rural, Santa Maria, v. 38, n. 7, p. 1961-1965, 2008.

BOBANY, D.M. et al. Atividade antimicrobiana do mel da abelha jataí (Tetragonisca angustula) em cultivo de microrganismos do conduto auditivo de caninos domésticos (Canis familiares). Ciência Animal Brasileira, Goiana, v. 11, n. 2, p. 441-446, 2010 .

BAZONI, M.O. Atividade antimicrobiana do mel produzido por Apis mellifera e abelhas sem ferrão nativas do Brasil. 2012. $116 \mathrm{f}$. Tese (Doutorado em Ciências: Área de Concentração em Genética) Faculdade de Medicina de Ribeirão Preto, Universidade de São Paulo, Ribeirão Preto, 2012.

BONFIM, G.F. Atividade antimicrobiana de microrganismos isolados de cupinzeiros da região da Mata do Cipó, Bahia. 2010. 67 f. Dissertação (Mestrado em Biotecnologia: Área de concentração em Biotecnologia com ênfase em recursos naturais da região Nordeste) - Universidade Estadual de Feira de Santana, Feira de Santana, 2010.

CONTI, R.; GUIMARÃES, D. O.; PUPO, M. T. Aprendendo com as interações da natureza: microrganismos simbiontes como fonte de produtos naturais bioativos. SBPC:Ciência e Cultura, São Paulo, v. 64, n 3, p. 43-47, 2012.

GARRITY G. M.; BELL, J. A.; LILBURN, T. G. Taxonomic Outline of the Prokaryotes. Bergey's Manual of Systematic Bacteriology. 2. ed. New York: Springer-Verlag. 2004. 401 p.

GILLIAM, M., ROUBIK, D. W., LORENZ, B. J. Microorganisms associated with pollen, honey, and brood provisions in the nest of a stingless bee, Melipona fasciata. Apidologie, Paris, v. 21, n. 2, p. 89-97, 1990.

GONÇALVES, A. L.; ALVES FILHO, A.; MENEZES, $H$. atividade antimicrobiana do mel da abelha nativa sem ferrão Nanotrigona testaceicornis (Hymenoptera: Apidae: Meliponini). Arquivos do Instituto Biológico, São Paulo, v. 72, n. 4, p. 455-459, 2005.

GUIMARÃES, D. O.; MOMESSO, L. S.; PUPO, M. T. Antibióticos: importância terapêutica e perspectiva para a descoberta e desenvolvimento de novos agentes. Química Nova, São Paulo, v. 33, n. 3, p. 667-679, 2010.

OLAITAN, P. B.; ADELEKE, O. E.; OLA, I. O. Honey: a reservoir for microorganisms and an inhibitory agent for microbes. African Health Sciences, Kampala, v. 7, n. 3, p. 159-165, 2007.

MATOS, I. T. S. R. et al. Qualidade microbiológica do mel de Meliponasp produzido na Amazônia Central (Parintis-AM-Brasil). Revista Verde, Mossoró, v. 6, n. 4, p. 91-95, 2011. 
MATSUURA, T. Caracterização de actinomicetos endofíticos produtores de antibióticos isolados cupuaçuzeiros (Theobroma grandiflorum Schum.). 2004. 68 f. Tese (Doutorado em Ciências de Alimentos: Área de concentração em Tecnologias de alimentos). Universidade Estadual de Campinas, Campinas, 2004.

MELLO, H. Bacillus cereuse e Bacillus subtilis na suplementação dietária de juvenis de Tilápias-do-Nilo (Oreochromis niloticus) e seu efeito probiótico. 2012. 57 f. Dissertação (Mestrado em Aquicultura e Pesca: Área de concentração em Aquicultura) - Universidade Estadual Paulista, São Paulo, 2012.

MONTE, A. L. Qualidade de méis de abelhas nativas sem ferrão do Estado do Piaui, Brasil. Revista Brasileira de Medicina Veterinária, Rio de Janeiro, v. 1, n. 35, p. 48-54, 2013.

PERALTA, E.D. Atividade antimicrobiana e composição química de méis do estado da Bahia. 2010. 265 f. Tese (Doutorado em Biotecnologia: Área de concentração em Biotecnologia com ênfase em recursos naturais da região Nordeste) Universidade Estadual de Feira de Santana, Feira de Santana, 2010.

REZENDE, C. S. M. et al. Ácido acético em rações de frangos de corte experimentalmente contaminadas com Salmonella enteritidis e Salmonella Typhimurium. Revista Brasileira de Saúde e Produção Animal, Salvador, v. 9, n. 3, p. 516-528, 2008.

ROCHA, A. P. et al. Prebióticos, ácidos orgânicos e probióticos em rações para frangos de corte. Revista Brasileira de Saúde e Produção Animal, Salvador, v. 11, n. 3, p. 793-801, 2010.

SILVA, N.; JUNQUEIRA, V. C. A.; SILVEIRA, N. F. A. Manual de métodos de análise microbiológica de Alimentos. 2. ed. São Paulo, SP: Varela, 2001. 317 p.

SOUZA, B. A. et al. Avaliação microbiológica do mel de Trigonineos (Apidae: Trigonini) do Estado da Bahia. Ciência e Tecnologia de Alimentos, Campinas, v. 29, n. 4, p. 798-802, 2009.

SOUZA, B. A. Caracterização físico-química e qualidade microbiológica do mel de abelhas sem ferrão (Apidae: Meliponinae) no Estado da Bahia, com ênfase em Melipona Illiger, 1806. 2008. 108 f. Tese (Doutorado em Ciências: Área de Concentração em Entomologia) - Escola Superior de Agricultura Luiz de Queiroz, Piracicaba, 2008. salivarius Strain and purification of its bacteriocin, which is inhibitory to Campylobacter jejuni in the chicken gastrointestinal system.Antimicrobial Agents Chemotherapy.Washington, v. 50, n. 9, p. 3111-3116, 2006.

VITTORI, J. et al. Qualidade microbiológica de leite UHT caprino: pesquisa de bactérias dos gêneros Staphylococcus, Bacillus e Clostridium. Ciência Rural, Santa Maria, v. 38, n. 3, p. 761-765, 2008.

STERN, N.J. et al. Isolation of a Lactobacillus 